\title{
NKG2-D Type II Integral Membrane Protein
}

National Cancer Institute

\section{Source}

National Cancer Institute. NKG2-D Type /l Integral Membrane Protein. NCI Thesaurus.

Code C101752.

NKG2-D type II integral membrane protein (216 aa, $25 \mathrm{kDa}$ ) is encoded by the human

KLRK1 gene. This protein plays a role in ligand-mediated NK cell activation. 